\title{
RASIO ASUPAN KALSIUM DAN ASUPAN FOSFOR SERTA AKTIVITAS FISIK TERKAIT NILAI BONE MASS DENSITY (BMD) PADA LANSIA OSTEOPOROSIS
}

\author{
Ardiani Listianingrum ${ }^{1}$; Diniyah Kholidah ${ }^{1}$; Sutomo Rum Teguh K ${ }^{1}$ \\ ${ }^{1}$ Politeknik Kesehatan Kemenkes Malang J1. Besar Ijen No.77C Malang \\ ardianilistia@gmail.com
}

\section{(Ratio Of Calcium Intake And Phosphoric Assumptions And Physical Activities Related To Bone Mass Density (Bmd) In Osteoporosis Lances)}

\begin{abstract}
Abstrak: Kepadatan tulang dipengaruhi faktor genetik, jenis kelamin, status gizi, asupan zat gizi (kalsium dan fosfor) dan gaya hidup seperti aktivitas fisik, merokok, konsumsi kafein dan alkohol yang berlebihan. (Janice LT, 2008). Tujuan penelitian ini adalah diketahuinya rasio asupan kalsium dan asupan fosfor serta aktivitas fisik terkait nilai bone mass density (BMD) pada lansia osteoporosis. Desain penelitian yang digunakan yaitu descriptive observasional. Penelitian ini dilaksanakan pada bulan April 2018 di Poli Lansia RSIA Puri Malang dengan 32 subyek penelitian. Analisis yang digunakan adalah analisis deskriptif kualitatif. Berdasarkan hasil analisis didapatkan asupan kalsium pada lansia terdapat 32 responden $(100 \%)$ termasuk kategori defisit tingkat berat. Rata-rata asupan kalsium responden yaitu $474,8 \mathrm{mg}$. Sedangkan asupan fosfor pada lansia terdapat 16 responden $(50 \%)$ termasuk kategori diatas AKG. Rata-rata asupan fosfor responden yaitu 890,6 mg. Kesesuaian rasio asupan kalsium dan fosfor terdapat 2 responden $(6,25 \%)$ dengan kesesuaian rasio $\leq 1,5$. Pada aktivitas fisik terdapat 16 responden (50\%) memiliki kategori aktifitas fisik sedang dan 16 responden (50\%) kategori aktifitas fisik ringan. Hal ini menunjukkan bahwa semakin rendah nilai Bone Mass Density (BMD) yaitu <-3,0 maka aktivitas fisik yang dilakukan oleh responden semakin ringan. Sedangkan semakin rendahnya nilai Bone Mass Density (BMD) yaitu <3,0 maka rasio asupan kalsium dan fosfor responden semakin tinggi. Perlu dilakukan upaya pencegahan terjadinya osteoporosis pada pasien lansia yaitu dengan pemberian edukasi untuk merubah pengetahuan pasien mengenai pentingnya pengaturan asupan makanan terutama asupan kalsium dan fosfor serta aktivitas fisik.
\end{abstract}

Kata Kunci: Osteoporosis, Rasio Kalsium dan Fosfor, Aktivitas Fisik, Nilai Bone Mass Density

Abstract: Bone density is influenced by genetic factors, gender, nutritional status, nutrient intake (calcium and phosphorus) and lifestyle such as physical activity, smoking, excessive consumption of caffeine and alcohol. (Janice LT, 2008). The purpose of this study was to find out the ratio intake of calcium and phosphorus and physical activity related to the value of bone mass density (BMD) in elderly osteoporosis. The research design used is observational descriptive. This research was conducted in April 2018 at the Elderly Poli of RSIA Puri Malang with 32 research subjects. The analysis used is qualitative descriptive analysis. Based on the results of the analysis found that calcium intake in the elderly there were 32 respondents $(100 \%)$ included in the severe deficit category. The average respondents calcium intake is $474.8 \mathrm{mg}$. While phosphorus intake in the elderly there were 16 respondents $(50 \%)$ included in the category above AKG. The average intake of phosphorus respondents is 890.6 mg. Suitability ratio of calcium and phosphorus intake is 2 respondents $(6.25 \%)$ with a suitability ratio of $\leq 1.5$. In physical activity there were 16 respondents $(50 \%)$ having moderate physical activity categories and 16 respondents (50\%) categories of mild physical activity. This shows that the lower the value of Bone Mass Density (BMD) is <3.0, the physical activity carried out by respondents is lighter. While the lower value of Bone Mass Density (BMD) is $<3.0$, the ratio of calcium and phosphorus intake of respondents is higher. 
Efforts should be made to prevent osteoporosis in elderly patients by providing education to change patients' knowledge of the importance of regulating food intake, especially calcium and phosphorus intake and physical activity.

Keywords: Osteoporosis, Ratio of Calcium and Phosphorus, Physical Activity,Value Bone Mass Density

\section{PENDAHULUAN}

Di negara berkembang insiden penyakit degeneratif terus meningkat sejalan dengan meningkatnya usia harapan hidup. Rata-rata usia harapan hidup penduduk Indonesia tahun 2014 adalah 72 tahun. Seiring dengan meningkatnya usia harapan hidup di Indonesia maka terjadi peningkatan penyakit degeneratif dan metabolik, termasuk osteoporosis.

Osteoporosis dapat dijumpai di seluruh dunia dan sampai saat ini masih merupakan masalah dalam kesehatan masyarakat terutama di negara berkembang. Menurut hasil data yang dilakukan oleh Puslitbang Gizi Depkes pada 14 provinsi menunjukkan bahwa masalah osteoporosis di Indonesia telah mencapai tingkat yang perlu diwaspadai yaitu 19,7\% (Depkes RI, 2004). Provinsi Jawa Timur termasuk memiliki risiko osteoporosis tertinggi yaitu sebesar 21,42\%. (Prasetya dkk, 2015)

Osteoporosis merupakan penipisan massa tulang sehingga tulang menjadi rapuh (fragil) dan mudah patah (Nurrahmani, 2015). Kepadatan mineral tulang merupakan kunci untuk menentukan besar risiko terjadinya osteoporosis. Osteoporosis ditandai dengan menurunnya kekuatan tulang dan meningkatnya kerapuhan yang disebabkan oleh kepadatan tulang yang rendah. Dikatakan berisiko osteoporosis jika memiliki T-score BMD $\leq-2,5 \mathrm{SD}$. (Tandra, 2009)

Kepadatan tulang dapat dipengaruhi oleh faktor genetik, jenis kelamin, status gizi, asupan zat gizi dan gaya hidup seperti aktivitas fisik, merokok, konsumsi kafein dan alkohol yang berlebihan. Asupan zat gizi mikro yang sangat berperan mempengaruhi kepadatan tulang yaitu kalsium dan fosfor. Kalsium dan fosfor dibutuhkan untuk proses mineralisasi tulang sehingga dapat menurunkan risiko kehilangan massa tulang (Janice LT, 2008).

Asupan fosfor yang berlebihan dalam bentuk fosfat dapat mengganggu rasio kalsium : fosfat, terutama jika asupan kalsium rendah. Hal ini dapat mengakibatkan menurunnya konsentrasi ion kalsium dalam serum sehingga menstimulasi hormon paratiroid untuk meningkatkan aktivitas osteoklas, sehingga dalam waktu yang lama dapat menyebabkan bone loss (Anderson, JJB, 2008).

Kurangnya aktivitas fisik di masa muda akan berdampak pada penurunan kepadatan tulang di masa lanjut usia (Hoger dan Hoeger, 2005). Aktivitas fisik merupakan hal penting dalam proses osteoblas (pembentukan tulang) dan kepadatan massa tulang.

Dari uraian diatas penulis ingin melakukan penelitian tentang asupan kalsium, asupan fosfor dan aktivitas fisik terkait nilai bone mass density (BMD) pada lansia.

\section{METODE PENELITIAN}

Desain penelitian yang digunakan
adalah penelitian descriptive
observasional yaitu menganalisa
hubungan rasio asupan kalsium, asupan
fosfor, serta aktivitas fisik terkait nilai
bone mass density (BMD) pada lansia
osteoporosis. Besar sampel yang
digunakan dalam penelitian ini
sebanyak 32 lansia osteoporosis.
Penelitian ini dilakukan pada 26 - 28
April 2018 di Poli Lansia RSIA Puri


Malang.

Pengumpulan data dilakukan dengan wawancara menggunakan form Semi-Quantitative Food Frequency Questionnaire untuk mengetahui asupan kalsium dan fosfor serta form aktivitas fisik untuk mengetahui aktivitas fisik lansia.

\section{HASIL DAN PEMBAHASAN}

\section{A. Gambaran Umum RSIA Puri Malang}

RSIA Puri Malang merupakan sebuah Rumah Sakit Ibu dan Anak di kota Malang yang telah beroperasi sejak tahun 2011. Rumah Sakit Ibu dan Anak PURI adalah suatu Rumah Sakit Swasta milik perorangan yang telah mendapat izin operasional dari Dinas Kesehatan Propinsi Jawa Timur No.445/6/35.73.112/2011 tanggal 19 Desember 2011.

\section{B. Poli Lansia RSIA Puri Malang}

Poli Lansia RSIA Puri Malang merupakan salah satu Poli Rawat Jalan yang berada di bawah Poli KIA (Konsultasi Ibu dan Anak) yang ada di RSIA Puri Malang. Poli Lansia RSIA Puri Malang memiliki 156 pasien lansia terdaftar yang rutin melakukan pengecekan kesehatan. Kegiatan yang ada di Poli Lansia salah satunya adalah senam lansia yang dilakukan setiap hari Rabu dan Jumat setiap minggunya.

C. Gambaran Umum Responden

1. Distribusi Responden menurut Jenis kelamin dan Kelompok Umur

Tabel 1. Distribusi Responden berdasarkan Jenis Kelamin

\begin{tabular}{|c|c|c|c|}
\hline No & $\begin{array}{c}\text { Jenis } \\
\text { Kelamin }\end{array}$ & $\mathrm{n}$ & $\%$ \\
\hline 1 & Laki-laki & 6 & 18,75 \\
\hline
\end{tabular}

\begin{tabular}{|c|c|c|r|}
\hline 2 & Perempuan & 26 & 81,25 \\
\hline & Jumlah & 32 & 100,00 \\
\hline
\end{tabular}

Berdasarkan tabel 1 dapat diketahui jumlah responden lakilaki sebanyak 6 orang $(18,75 \%)$ dan perempuan sebanyak 26 orang (81,25\%). Banyaknya jumlah responden perempuan yang lebih besar dibandingkan laki-laki dikarenakan perempuan terjadi menopause dan berkurangnya hormon esterogen sehingga berisiko mengalami osteoporosis.

Osteoporosis banyak dialami oleh wanita, namun tidak menutup kemungkinan terjadi pada pria. Hal ini disebabkan pria mempunyai massa tulang yang lebih padat dan proses demineralisasi tulang pada pria juga lebih lambat daripada wanita. Berdasarkan catatan National Osteoporosis Foundation sebesar $\quad 80 \% \quad$ osteoporosis ditemukan pada wanita. Ketidakseimbangan reabsorpsi dan formasi tulang paling sering disebabkan oleh menopause pada wanita (Tandra, 2009).

Tabel 2. Distribusi Responden berdasarkan Kelompok Umur

\begin{tabular}{|c|c|c|c|}
\hline No & $\begin{array}{c}\text { Kelompok } \\
\text { Umur } \\
\text { (tahun) }\end{array}$ & n & $\%$ \\
\hline 1 & $60-70$ & 21 & 65,63 \\
\hline 2 & $70-80$ & 11 & 34,37 \\
\hline & Jumlah & 32 & 100,00 \\
\hline
\end{tabular}

Tabel 2 menunjukkan bahwa responden lansia terbanyak adalah kelompok umur $60-70$ tahun yaitu 21 orang dengan persentase 65,63\%. Menurut Rukmoyo (2012), pada usia 60-70 tahun lebih dari $30 \%$ perempuan menderita osteoporosis dan insidennya meningkat menjadi 
$70 \%$ pada usia 80 tahun ke atas.

Lane (dalam Wardhana, 2012), menyebutkan bahwa setelah usia 30 tahun, massa tulang yang hilang akan lebih banyak daripada massa tulang yang dibentuk, sehingga dengan meningkatnya usia, massa tulang akan semakin berkurang.

2. Distribusi Responden menurut Jenis Pekerjaan

Tabel 3. Distribusi Responden berdasarkan Jenis Pekerjaan

\begin{tabular}{|c|l|c|r|}
\hline No & $\begin{array}{c}\text { Jenis } \\
\text { Pekerjaan }\end{array}$ & $\mathrm{n}$ & \multicolumn{1}{c|}{$\%$} \\
\hline 1 & Karyawan & 8 & 25,00 \\
\hline 2 & Wirausaha & 3 & 9,38 \\
\hline 3 & $\begin{array}{l}\text { Tidak } \\
\text { Bekerja }\end{array}$ & 21 & 65,62 \\
\hline & Jumlah & 32 & 100,00 \\
\hline
\end{tabular}

Tabel 3 menunjukkan bahwa responden yang tidak bekerja sebanyak 21 orang dengan persentase $65,62 \%$. Responden yang tidak bekerja terdiri dari ibu rumah tangga dan pensiunan. Pekerjaan mempengaruhi pendapatan keluarga yang akan menggambarkan kemampuan dalam memenuhi kebutuhan sehari-hari terutama menyediakan makanan dalam keluarga.

Berg (dalam Prasetya, 2013) menyatakan bahwa pekerjaan memiliki kaitan yang erat dengan pendapatan keluarga. Pendapatan merupakan faktor yang paling menentukan terhadap kuantitas dan kualitas makanan yang dikonsumsi. Hartatik (2016), pekerjaan akan mempengaruhi pendapatan yang akan meningkatkan daya beli untuk memenuhi kebutuhan, sehingga meningkatkan asupan makanan.

3. Distribusi Responden menurut Tingkat Pendidikan
Tabel 4. Distribusi Responden berdasarkan Tingkat Pendidikan

\begin{tabular}{|c|l|c|c|}
\hline No & $\begin{array}{c}\text { Tingkat } \\
\text { Pendidikan }\end{array}$ & $\mathrm{n}$ & $\%$ \\
\hline 1 & Rendah & 14 & 43,75 \\
\hline 2 & Tinggi & 18 & 56,25 \\
\hline & Jumlah & 32 & 100,00 \\
\hline
\end{tabular}

Tabel 4 menunjukkan bahwa responden yang memiliki tingkat pendidikan tinggi yaitu sebanyak 18 orang dengan persentase $56,25 \%$. Menurut Khosman (2000), tingkat pendidikan digolongkan 2 kategori yaitu rendah dan tinggi. Kategori rendah apabila tidak tamat sekolah, tidak tamat SD, tidak tamat SMP/sederajat dan kategori tinggi yaitu tamat SMA/sederajat atau diatasnya.

Tingkat pendidikan berdampak pada wawasan dan pengetahuan responden tentang pola makan makanan tinggi kalsium yang baik untuk pencegahan osteoporosis pada lansia. Responden yang berpendidikan tinggi mempunyai pengetahuan yang lebih luas dibandingkan dengan berpendidikan rendah. Menurut Rizkiyah (dalam Marjan, 2013), tingkat pendidikan memiliki pengaruh terhadap kejadian osteoporosis. Wanita dengan tingkat pendidikan yang tinggi mempunyai peluang 5 kali untuk memiliki sikap mendukung pencegahan osteoporosis dibandingkan wanita dengan tingkat pendidikan rendah. Tingkat pendidikan dan kemampuan sosial yang rendah pada masyarakat mempengaruhi kualitas dan kuantitas makanan yang dikonsumsi (Winarno, 1997).

D. Asupan Kalsium, Fosfor, serta Rasio 
Asupan Kalsium dan Fosfor

1. Asupan Kalsium Responden

Hasil penelitian menunjukkan $100 \%$ semua subjek pada penelitian ini asupan kalsium termasuk kategori defisit tingkat berat. Asupan kalsium terendah yaitu 116,1 $\mathrm{mg}$ dan asupan kalsium tertinggi yaitu 803,3 mg. Rata-rata asupan kalsium responden adalah 474,8 $\mathrm{mg} /$ hari. Angka tersebut jauh dari kecukupan kalsium lansia yaitu $1.000 \mathrm{mg} / \mathrm{hari}$ (AKG, 2013).

Rendahnya asupan kalsium dari kebutuhan dapat dipengaruhi oleh rendahnya makanan sumber kalsium yang dikonsumsi. Hasil Semi-Quantitative Food Frequency Questionnaire yaitu konsumsi susu pada responden rendah, penyebabnya yaitu responden tidak suka minum susu dan harga susu yang tidak terjangkau. Menurut Lutfiah (dalam Citerawati, 2014), salah satu penelitian menunjukkan bahwa apabila susu dan produk susu tidak dikonsumsi maka akan sulit untuk mendapatkan asupan kalsium yang cukup, kecuali ditambah dengan konsumsi tablet kalsium.

Selain itu asupan kalsium yang rendah dipengaruhi oleh proses penuaan. Proses penuaan menjadikan penyerapan kalsium dalam usus menjadi lebih rendah sehingga pengaruhnya terhadap kepadatan tulang menjadi rendah. Defiensi hormon esterogen akibat menopause membuat penyerapan kalsium menjadi rendah.

2. Asupan Fosfor Responden

Tabel 5. Distribusi Responden berdasarkan Asupan Fosfor

\begin{tabular}{|c|c|c|c|}
\hline No & $\begin{array}{c}\text { Asupan } \\
\text { Fosfor }\end{array}$ & $\mathrm{n}$ & $\%$ \\
\hline 1 & Diatas & 16 & 50,00 \\
\hline
\end{tabular}

\begin{tabular}{|c|l|r|r|}
\hline & AKG & & \\
\hline 2 & Normal & 14 & 43,75 \\
\hline 3 & $\begin{array}{l}\text { Defisit } \\
\text { Tingkat } \\
\text { Berat }\end{array}$ & 2 & 6,25 \\
\hline & Jumlah & 32 & 100,00 \\
\hline
\end{tabular}

Perhitungan

dengan

kebutuhan fosfor didapatkan 50\% responden termasuk kategori diatas AKG. Asupan fosfor terendah yaitu 281,9 $\mathrm{mg}$ dan asupan fosfor tertinggi yaitu 1184,8 mg. Rata-rata asupan fosfor responden $890,6 \mathrm{mg} / \mathrm{hari}$. Angka tersebut lebih dari kecukupan fosfor yaitu 700 mg/hari (AKG, 2013).

Tingginya asupan fosfor berdasarkan kebutuhan dapat dipengaruhi oleh tingginya makanan sumber fosfor yang dikonsumsi. Asupan fosfor yang paling sering dikonsumsi responden berasal dari sumber lauk nabati yaitu tempe. Bahan makanan tersebut menyumbangkan fosfor sebanyak $154 \mathrm{mg}$ dalam 100 gram bahan makanan.

3. Kategori Rasio Asupan Kalsium dan Asupan Fosfor

Berdasarkan gambar 1 terlihat bahwa dari 32 responden terdapat 2 responden $(6,25 \%)$ dengan kesesuaian rasio $\leq 1,5$ dan 30 responden $(93,75 \%)$ dengan kesesuaian rasio > 1,5. Rasio lebih dari 1,5 mengartikan bahwa rasio antara kalsium dan fosfor adalah lebih dari $1: 1,5$.

Kalsium dan fosfor saling berpengaruh erat dalam absorpsi kalsium. Rasio rata-rata asupan kalsium : fosfor adalah 1 : 1,5. Hal ini menunjukan bahwa asupan fosfor yang dikonsumsi relatif lebih tinggi terhadap asupan kalsium. Tetapi rasio yang 
lebih dari $1: 2$ terutama jika konsumsi kalsium rendah akan menyebabkan pengaruh negatif seperti demineralisasi tulang.

Menurut Asrar (dalam Sari, 2016), homeostasis fosfor terutama ditentukan oleh asupan makanan, penyerapan usus, dan reabsorpsi tubulus ginjal fosfor. Namun bila asupan fosfor relatif tinggi terhadap kalsium maka akan diperoleh rasio kalsium : fosfor yang tidak seimbang dalam serum sehingga akan merangsang pembentukan PTH (hormon paratiroid) yang mendorong pengeluaran fosfor dari tubuh. Asupan tinggi fosfor dapat mengakibatkan peningkatan sekresi serum PTH (hormon paratiroid) dan mempengaruhi metabolisme tulang. Dalam jangka panjang, asupan tinggi fosfor bisa menyebabkan hiperparatiroidisme sekunder, peningkatan resorpsi tulang, dan rendahnya kualitas tulang, terutama jika asupan kalsium tidak memadai.

Kesesuaian antara asupan kalsium dan fosfor dapat dilihat pada gambar 1 dibawah ini:

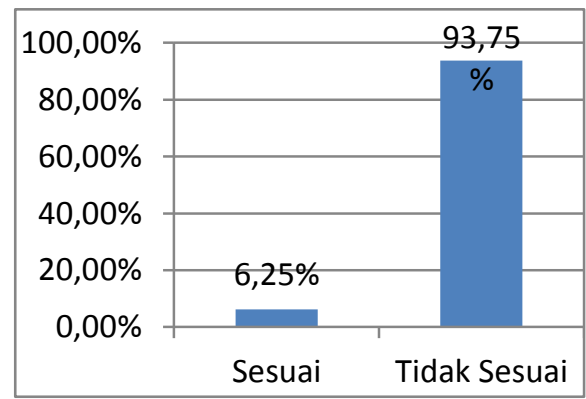

Gambar 1. Kesesuaian Asupan Kalsium dan Fosfor

E. Aktivitas Fisik Responden

Tabel 6. Distribusi Responden berdasarkan Aktivitas Fisik

\begin{tabular}{|c|l|c|c|}
\hline No & $\begin{array}{c}\text { Aktivitas } \\
\text { Fisik }\end{array}$ & n & $\%$ \\
\hline 1 & Ringan & 16 & 50,00 \\
\hline
\end{tabular}

\begin{tabular}{|c|c|c|c|}
\hline 2 & Sedang & 16 & 50,00 \\
\hline & Jumlah & 32 & 100,00 \\
\hline
\end{tabular}

Hasil penelitian aktivitas fisik pada tabel 6 menunjukkan bahwa responden lansia memiliki aktivitas fisik dalam kategori ringan sebesar $50 \%$ sedangkan $50 \%$ tergolong dalam kategori sedang. Aktivitas fisik erat kaitannya dengan nilai BMD (bone mass density).

Tabel 7. Beda Aktivitas Fisik pada Lansia

\begin{tabular}{|c|c|c|c|c|c|}
\hline No & $\begin{array}{c}\text { Aktivitas } \\
\text { Fisik }\end{array}$ & Mean & Median & Min & Max \\
\hline 1 & Ringan & 1,57 & 1,55 & 1,44 & 1,65 \\
\hline 2 & Sedang & 1,79 & 1,85 & 1,71 & 1,87 \\
\hline
\end{tabular}

Hasil penelitian menunjukkan median level aktivitas fisik ringan berada pada 1,55 sedangkan aktivitas fisik sedang berada pada 1,85. Pada aktivitas fisik ringan didapatkan nilai rata-ratanya yaitu 1,57 dimana nilai tersebut berada pada nilai tengah aktivitas fisik kategori ringan yaitu 1,55. Hal ini berarti responden memiliki aktivitas fisik yang bagus karena cenderung kearah batas atas yaitu 1,65.

Sebagian besar responden lakilaki maupun perempuan memiliki aktifitas fisik yang bagus, karena responden memiliki kesadaran mengikuti kelompok lansia dalam berolahraga seperti senam lansia.

Menurut Whitney (dalam Marjan, 2013), kebiasaan beraktivitas fisik seseorang berdampak pada kepadatan tulang di masa lanjut usia. Begitu pula dengan pekerjaan, semakin berat dan lama pekerjaan seseorang, maka semakin berat pula aktivitas fisiknya.

F. Nilai Bone Mass Density (BMD) Responden

Hasil penelitian menunjukkan bahwa responden yang memiliki nilai BMD (bone mass density) 
terendah sebanyak 24 responden dengan persentase $75 \%$. Rata-rata nilai BMD (bone mass density) responden yang rendah yaitu $-2,65$. Adapun faktor yang mempengaruhi nilai BMD (bone mass density) yaitu umur, jenis kelamin, asupan kalsium dan fosfor serta aktivitas fisik yang cukup. (Janice, 2008)

Menurut The National Institutes of Health (dalam Setyawati, 2013), perlunya perhatian serius diberikan kepada rentang usia pencapaian puncak pembentukan massa tulang yaitu pada usia 25-35 tahun. Secara umum setelah masa puncak pencapaian massa tulang (peak bone mass), densitas tulang secara berangsur-angsur akan menurun seiring dengan pertambahan usia yaitu pada usia 60 - 80 tahun yang memiliki resiko tinggi osteoporosis.

Distribusi nilai Bone Mass Density (BMD) pada responden danat dilihat nada gambar 2 dibawah

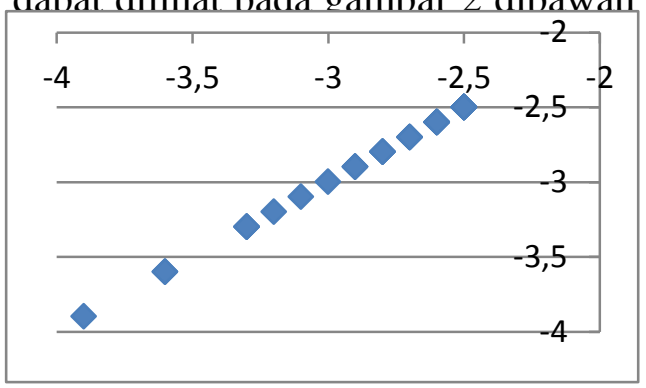

Gambar 2. Distribusi Lansia berdasarkan Nilai Bone Mass Density (BMD)

G. Analisis Hubungan Rasio Asupan Kalsium dan Fosfor serta Aktivitas Fisik dengan Nilai Bone Mass Density (BMD)

Rata-rata responden yang memiliki nilai Bone Mass Density (BMD) $\quad-2,5-\quad-3,0$ memiliki kecenderungan aktivitas fisik sedang. Sedangkan responden dengan nilai Bone Mass Density (BMD) $<-3,0 \quad$ memiliki kecenderungan aktivitas fisik ringan. Dapat disimpulkan bahwa semakin rendah nilai Bone Mass Density (BMD) yaitu <-3,0 maka aktivitas fisik yang dilakukan oleh responden semakin ringan. Karena pada pasien yang memiliki nilai Bone Mass Density (BMD) rendah $(<-3,0)$ berisiko mengalami cedera atau trauma fisik sehingga dapat mengakibatkan fraktur.

Aktivitas fisik yang dilakukan setiap orang berbeda-beda. Dengan aktivitas fisik, berarti otot tubuh bergerak dan menghasilkan energi (Agustin dalam Nugroho 2017). Menurut Katz (dalam Kosnayani, 2007) menambahkan bahwa aktivitas fisik, khususnya aktivitas yang menumpu beban, dan latihan yang rutin akan menambah kepadatan dan kekuatan tulang sejalan dengan bagusnya asupan zat gizi. Hal ini menunjukkan bahwa untuk mempertahankan nilai Bone Mass Density (BMD) memerlukan proses aktivitas fisik yang rutin dan diimbangi dengan asupan kalsium dan fosfor yang seimbang sehingga mengurangi risiko fraktur.

Responden yang memiliki nilai Bone Mass Density (BMD) -2,5 - 3,0 memiliki kecenderungan rasio asupan kalsium dan fosfor rendah yaitu dengan rata-rata rasio 1:1,9. Sedangkan responden dengan nilai Bone Mass Density (BMD) <-3,0 memiliki rasio asupan kalsium dan fosfor tinggi yaitu rata-rata rasio $1: 2,1$. Dapat disimpulkan bahwa semakin rendahnya nilai Bone Mass Density (BMD) yaitu <-3,0 maka rasio asupan kalsium dan fosfor responden semakin tinggi.

Rasio asupan kalsium dan fosfor harus berada dalam keadaan proporsional sehingga dapat menjalankan proses mineralisasi. Menurut Gibson (dalam Citerawati, 2014), rasio lebih dari $1: 1,5$ harus 
diperhatikan karena asupan tinggi fosfor akan mengurangi kehilangan kalsium lewat urin, akan tetapi meningkatkan kehilangan kalsium lewat feses pada waktu yang bersamaan. Hal ini akan menyebabkan ketidakseimbangan antara asupan kalsium dan asupan fosfor sehingga mengakibatkan sekresi serum PTH (hormon paratiroid) yang akan mempengaruhi metabolisme tulang.

\section{KESIMPULAN}

1. Asupan kalsium pada lansia terdapat 32 responden (100\%) termasuk kategori defisit tingkat berat. Asupan kalsium terendah yaitu 116,1 mg dan asupan kalsium tertinggi yaitu 803,3 mg. Rata-rata asupan kalsium responden adalah 474,8 $\mathrm{mg} /$ hari.

2. Asupan fosfor pada lansia terdapat 16 responden (50\%) termasuk kategori diatas $\mathrm{AKG}, 14$ responden $(43,75 \%)$ kategori normal dan 2 responden $(6,25 \%)$ kategori defisit tingkat berat. Asupan fosfor terendah yaitu 281,9 $\mathrm{mg}$ dan asupan fosfor tertinggi yaitu $1184,8 \mathrm{mg}$. Rata-rata asupan fosfor responden 890,6 $\mathrm{mg} /$ hari.

3. Kesesuaian rasio asupan kalsium dan fosfor terdapat 2 responden $(6,25 \%)$ dengan kesesuaian rasio $\leq 1,5$ dan 30 responden $(93,75 \%)$ dengan kesesuaian rasio $>1,5$.

4. Aktivitas fisik 16 responden (50\%) memiliki kategori aktivitas fisik sedang dan 16 responden (50\%) kategori aktivitas fisik ringan. Nilai median aktivitas fisik ringan berada pada 1,55 sedangkan aktivitas fisik sedang berada pada 1,85. Pada aktivitas fisik ringan didapatkan nilai rata-ratanya yaitu 1,57 dimana nilai tersebut berada pada nilai tengah aktivitas fisik kategori ringan yaitu 1,55 .

5. Semakin rendah nilai Bone Mass
Density (BMD) yaitu <-3,0 maka aktivitas fisik yang dilakukan oleh responden semakin ringan. Sedangkan semakin rendahnya nilai Bone Mass Density (BMD) yaitu $<3,0$ maka rasio asupan kalsium dan fosfor responden semakin tinggi.

\section{SARAN}

Perlu dilakukan upaya pencegahan terjadinya osteoporosis lebih lanjut kepada pasien lansia rawat jalan di RSIA Puri Malang. Pemberian edukasi merupakan salah satu cara yang dapat dilakukan untuk merubah pengetahuan pasien rawat jalan lansia osteoporosis mengenai pentingnya pengaturan asupan makanan terutama asupan kalsium dan fosfor serta aktivitas fisik untuk mencegah terjadinya osteoporosis yang lebih parah.

\section{DAFTAR PUSTAKA}

1. Anderson, J.J.B. Nutrition and Bone Health. In: Mahan LK, Escott-Stump $S$, editors. Krause's Food and Nutrition Therapy. 12th ed. St. Louis: Saunders Elsevier; 2008; p. 614-635.

2. Citerawati, Y.W., Setijowati, N. dan Fadhilah, E. 2014. Hubungan Asupan Sumber Kalsium dengan Kejadian Menarche pada Remaja Putri. Skripsi Fakultas Kedokteran, Universitas Brawijaya.

3. Depkes RI. 2004. Kecenderungan Osteoporosis di Indonesia 6 Kali Lebih Tinggi dibandingkan Negeri Belanda. Jakarta: Litbangkes.

4. Hartatik, S. 2016. Tingkat Pengetahuan, Tingkat Konsumsi Energi, Protein Pasien Ginjal Kronik Hemodialisis Sebelum dan Sesudah Diberikan Konseling Gizi di Rumah Sakit Umum Daerah DR. Iskak Tulungagung. Skripsi Jurusan Gizi, Poltekkes Kemenkes Malang.

5. Hoger and Hoeger. 2005. Lifetime Physical Fitness and Wellness, a 
Personalized Prog, Edisi ke-5. Thomson Wadsworth, USA.

6. Janice, L.T., Melinda, M.M. and Linda, A.V. The Science of Nutrition 2nd ed. USA: Pearson Education, Inc 2008. P410-437.

7. Khomsan, A. 2000. Tehnik Pengukuran Pengetahuan Gizi. Jurusan Gizi Masyarakat dan Sumberdaya Keluarga. Fakultas Pertanian, IPB, Bogor.

8. Kosnayani, A. S. 2007. Hubungan Asupan Kalsium, Aktivitas Fisik, Paritas, Indeks Massa Tubuh dan Kepadatan Tulang pada Wanita Pascamenopause. Tesis Magister Gizi Masyarakat, Universitas Diponegoro.

9. Marjan, A.Q. 2013. Hubungan antara Pola Konsumsi Pangan dan Aktivitas Fisik dengan Kejadian Osteoporosis pada Lansia di Panti Werdha Bogor. Skripsi Fakultas Ekologi Manusia, Institut Pertanian Bogor.

10. Nugroho, I. S. P. Dan Muniroh, L. 2017. Hubungan Konsumsi Pangan Sumber Kalsium dan Aktivitas Fisik dengan Kepadatan Tulang Lacto Ovo Vegetarian di Yayasan Budha Tzu Chi Surabaya. Jurnal Media Gizi Indonesia, Volume 12 Nomor 1.

11. Nurrahmani, U. 2015. STOP! Osteoporosis. Yogyakarta: Familia.

12. Prasetya, D., Wirjatmadi, B. dan Adriani, M. 2015. Pengaruh Pemberian Susu yang Difortifikasi (Kalsium dan Vitamin D) dan Senam Osteoporosis terhadap Kepadatan Tulang pada Wanita Pra Lansia di Wilayah Kerja Puskesmas Banyuanyar Kabupaten Sampang. Jurnal Ilmiah Kedokteran Volume 4 Nomor 1.

13. Prasetyo, W.E. 2013. Hubungan Antara Tingkat Pendapatan Dan Pengeluaran Pangan-Non Pangan Keluarga Dengan Status Gizi Anak Prasekolah Di Kelurahan Semanggi
Dan Sangkrah, Kecamatan Pasar Kliwon, Surakarta. Fakultas Ilmu Kesehatan, Universitas Muhammadiyah Surakarta.

14. Rukmoyo, T. 2012. Buku Ajar Osteoporosis. Fakultas Kedokteran Universitas Gadjah Mada, Yogyakarta.

15. Sari, D.P., Kusudaryati, D.P.D. dan Noviyanti, R.D. 2018. Hubungan Kualitas Tidur dan Aktivitas Fisik dengan Tekanan Darah pada Lansia di Posyandu Lansia Desa Setrorejo. Media Publikasi Penelitian, Volume 15 Nomor 2.

16. Setyawati, B., Julianti, E.D dan Adha, D. 2013. Faktor yang Berhubungan dengan Densitas Mineral Tulang Perempuan Dewasa Muda Di Kota Bogor, Penelitian Gizi dan Makanan, Vol. 36 (2): 149156.

17. Tandra, H. 2009. Osteoporosis Mengenal, Mengatasi, dan Mencegah Tulang Keropos. Jakarta: Gramedia Pustaka Umum.

18. Wardhana, W. 2012. FaktorFaktor Risiko Osteoporosis pada Pasien dengan Usia Diatas 50 Tahun. Skripsi Fakultas Kedokteran, Universitas Diponegoro.

19. Winarno, F.G. 1997. Keamanan Pangan, ITB : Bandung. 